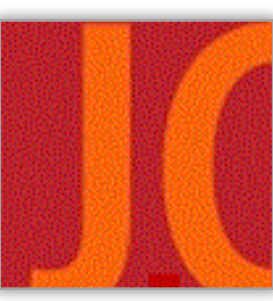

\title{
Walking: A Quiet Participation in Place
}

\author{
Josh Markle \\ University of Calgary \& University of Lethbridge \\ Sharon Pelech \\ University of Lethbridge
}

\begin{abstract}
:
We reflect on experiences we have had working, living and walking alongside our students. We interpret these experiences to reveal the silences at play as we walk stories into being together and attune ourselves to the places we both create and inhabit. We ground our exploration of the connection between walking and curriculum in life writing and literary métissage (HasebeLudt et al., 2009). Throughout, we draw inspiration from Abram (1996) to explore the notion of walking as quiet participation, which we characterize as a bodily attunement toward each other and the more-than-human world, and we point to its possibilities for how we work and live alongside one another.
\end{abstract}

Keywords: walking; métissage; hermeneutics; place; quiet participation 


\section{Marcher : \\ une participation tranquille en place}

\section{Résumé :}

Nous réfléchissons aux expériences que nous avons vécues en travaillant, en vivant et en marchant aux côtés de nos étudiants. Nous interprétons ces expériences pour révéler les silences en jeu alors que nous marchons des histoires ensemble et nous nous adaptons aux lieux que nous créons et habitons. Nous fondons notre exploration du lien entre la marche et le curriculum dans l'écriture de la vie et le métissage littéraire (Hasebe-Ludt et al., 2009). Tout au long, nous nous inspirons d'Abram (1996) pour explorer la notion de marche en tant que participation silencieuse, que nous caractérisons comme une harmonisation corporelle les uns envers les autres et le monde plus qu'humain, et nous signalons ses possibilités pour la façon dont nous travaillons et vivent côte à côte.

Mots clés : la marche; le métissage; I'herméneutique; le lieu; la participation tranquille 
A living language is continually being made and remade, woven out of the silence by those who speak. ... And this silence is that of our wordless participations, of our perceptual immersion in the depths of an animate, expressive world.

(Abram, 1996, p. 84)

\section{Introduction}

\section{(in which we take our first step)}

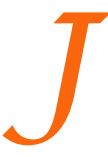

ohn Berger writes that, like many animals on earth, stories can walk, too. "Their steps are not only between narrative events," he writes, "but between each sentence, sometimes each word. Every step is a stride over something not said" (Berger \& Mohr, 1982, p. 285). Berger used walking as a metaphor, but we would like to take his idea one step further. In this paper, we put forth the idea of literal, physical walking as a means of attuning to the world. We do so from our perspectives as educators, as we draw on our experiences of walking, both with and without our students, as a means of attuning ourselves to story and place. As Pyne Feinburg (2016) notes, "attuned interaction with the environment while walking can build a pathway toward convening with the extraordinary in the ordinary" (p. 148). We ground our exploration of the connection between walking and curriculum in life writing and literary métissage (Hasebe-Ludt et al., 2009). We intend each narrative strand as a step between words as we walk together with our stories. Throughout, we draw inspiration from Abram (1996) to explore the notion of walking as quiet participation, which we characterize as a bodily attunement toward each other and the more-than-human world, and we point to its possibilities for how we work and live alongside one another.

\section{Second Step \\ (in which Josh follows a bird)}

One unintended consequence of the 2020 coronavirus pandemic has been the additional time I (Josh) have been given to spend closer to home, this spring. Lucky to be healthy, I have been afforded the opportunity to spend much of my time in our garden, or walking and running around our neighbourhood, time I would have normally spent visiting student teachers in their practicum schools throughout southern Alberta. I have been able to pay more attention to all the returning inhabitants of this place. The first few bumblebees of the season, for example, arrived as our cornflower bloomed. So too with the hawthorn trees, which filled with white blossoms and hundreds of Bohemian waxwings. And, as if set to a clock, the local turkey vultures returned to their seasonal roost in three tall spruce just a block from my home.

But there was one visitor to our neighbourhood who seemed to have lost her way. Around the beginning of June, I began to hear a bird call that was unfamiliar to me. It was almost like the ringing of an old rotary telephone.

didididididididididididididi . . . didididididididididididididi 
It was a solitary call, not the singsong volley of robins and sparrows. It rang out from the trees behind our house, sometimes just to the north, other times just to the south, always for a few hours each morning. She returned each day for weeks.

\section{didididididididididididididi . . . didididididididididididididi}

Curious, I purchased binoculars, determined to see this particular bird. I began to walk near my house each morning, following the lone and peripatetic call. I listened to bird calls on YouTube. I read birding books.

\section{didididididididididididididi . . . didididididididididididididi}

In one of my books, I found the onomatopoeia that matched the call of my co-inhabitant (Bird, 2010, p. 328). It belonged to the boreal chickadee. As the name suggests, this chickadee is typically found in the boreal region of Canada. A hardy little bird, which resides as far north as the Arctic Circle, it generally prefers spruce trees, which we have in our neighbourhood. But Lethbridge, where I live and work, is far south of the boreal chickadee's typical range. As I had guessed from the solitary call, this little bird was an errant traveler. Other chickadees make this area their home: the blackcapped chickadee is a familiar sight in our neighbourhood. The boreal chickadee lacks that striking juxtaposition of black and white that the black-capped possesses. The boreal is more earthy in colour, all peat and cinnamon. But its call is striking.

Rather than scan the tree line from my deck, I began to traverse the neighbourhood. One day, while following the chickadee's call, I began to think about how my walking had changed. I think we tend to walk at right angles: at an intersection, we might turn right or left, for example, and we typically look straight ahead, our sightlines parallel to the ground and perpendicular to our bodies. But looking for birds reorients the body. I found myself meandering down alleyways, my neck craned to look into the tree canopy. At times, I would hear the chickadee call from somewhere further afield, and my steps would hasten; at other times, I would subtend the street grid in long, slow arcs, drawn by her lonely call ringing through the trees. A chickadee travels similarly; its flight a series of glides punctuated by quick bursts. Although she would not yet reveal herself to me, it was as if we had found a shared cadence by some process of mimesis.

One morning, on my way home after another unsuccessful search, I stopped by the three tall spruce trees in which the turkey vultures make their summer home each year. A wake of about 15 preened and lumbered in the branches. Occasionally, one would stretch, exposing a wrinkled, crimson head atop a monk-like cowl of feathers. Their silence-their assuredness-seemed a counterpoint to the ringing call of my itinerant little chickadee.

When I returned to my house, I sat down in my backyard and began to think about the connection between place and home. Although my wife and I have lived in this house for three years, and in this city for the better part of a decade, it has never quite felt like home. But at that moment, I had never felt so comfortable and at home in a place. I could not help but think it took a wayward chickadee to make me feel that way. In travelling together, it seemed we had both blurred the 
"boundaries of belonging and exile" (Cariou, 2014, p. 37) that connect place and home. And then as if on cue:

didididididididididididididi . . . didididididididididididididi

I looked in the direction of the call and watched as a bird flitted towards my yard, eventually alighting in a bare branch of a neighbour's towering aspen.

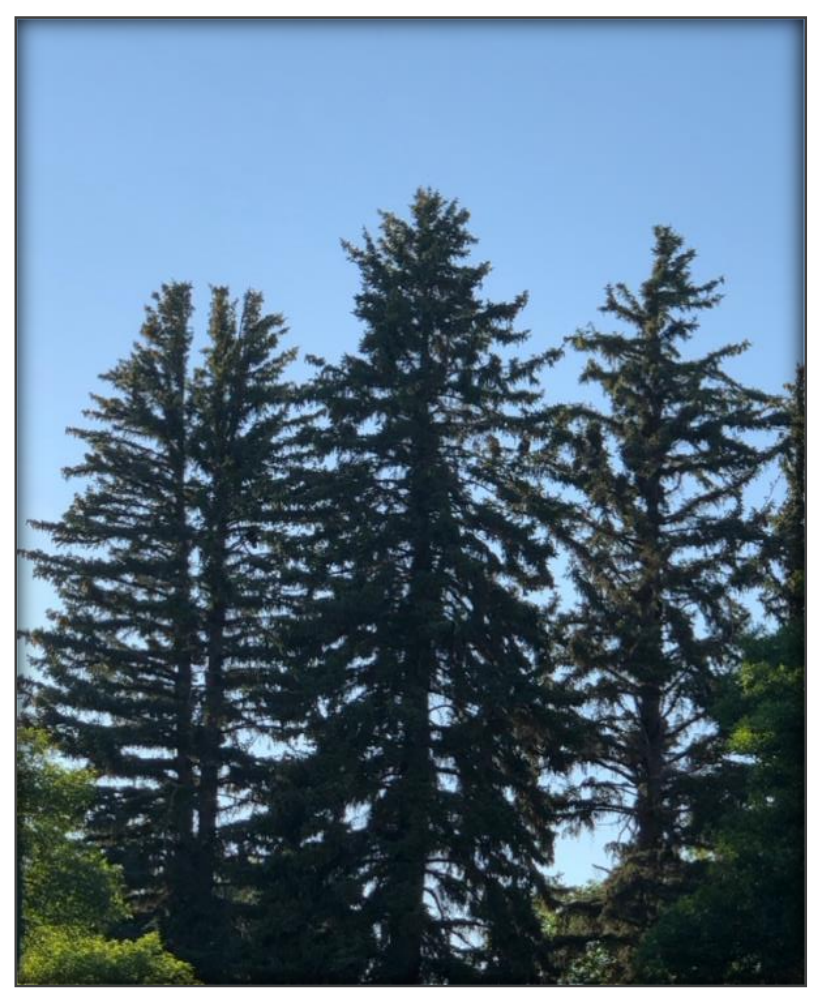

Three Spruce in the Neighborhood ${ }^{1}$

I raised my binoculars to watch this little bird crane its neck and utter the sound that had become so familiar to me.

didididididididididididididi . . . didididididididididididididi

\section{Third Step}

\section{(in which Sharon walks with pre-service teachers)}

I (Sharon) had moved to St. John's, Newfoundland, in 2012, to take on a new career in academia after nearly two decades of teaching in junior/senior high schools in Alberta. As the new science curriculum specialist in the education faculty at Memorial University of Newfoundland, I worked closely with a former teacher and sessional instructor, Robert Kelsey, to plan an overnight

${ }^{1}$ All photos are the work of the authors and are provided with permission. 
trip intended to help education students connect ecological learning to the science curriculum. As this was the first class the students took in the education program, they got on the bus primarily as strangers, but by the end of the two-day experience, they had formed strong bonds with each other. Our destination was the Brother Brennan Environmental Education Centre-a pristine natural habitat located about one and a half hours from the city of St John's. It is found in the midst of the Avalon Forest ecoregion and is situated in an old growth boreal forest of Deer Park, Salmonier. We endured a bumpy, rocky road en route to an area without roads, houses or other trappings of humans except the Environmental Centre which was our intended location. Brother Brennan Centre is set up as an outdoor environmental centre for students from across the island to visit and experience the wonderful flora and fauna that is found there.

Our first experience after arriving was to take a nature walk. We walked amongst the trees, climbing gentle hills to find open spaces, then ambled back down toward a hillside amidst large trees, rocks and spongy moss on either side of the path. After our walk, the centre leaders handed out blindfolds and instructed the students to find a comfortable spot along the trail in which to sit.

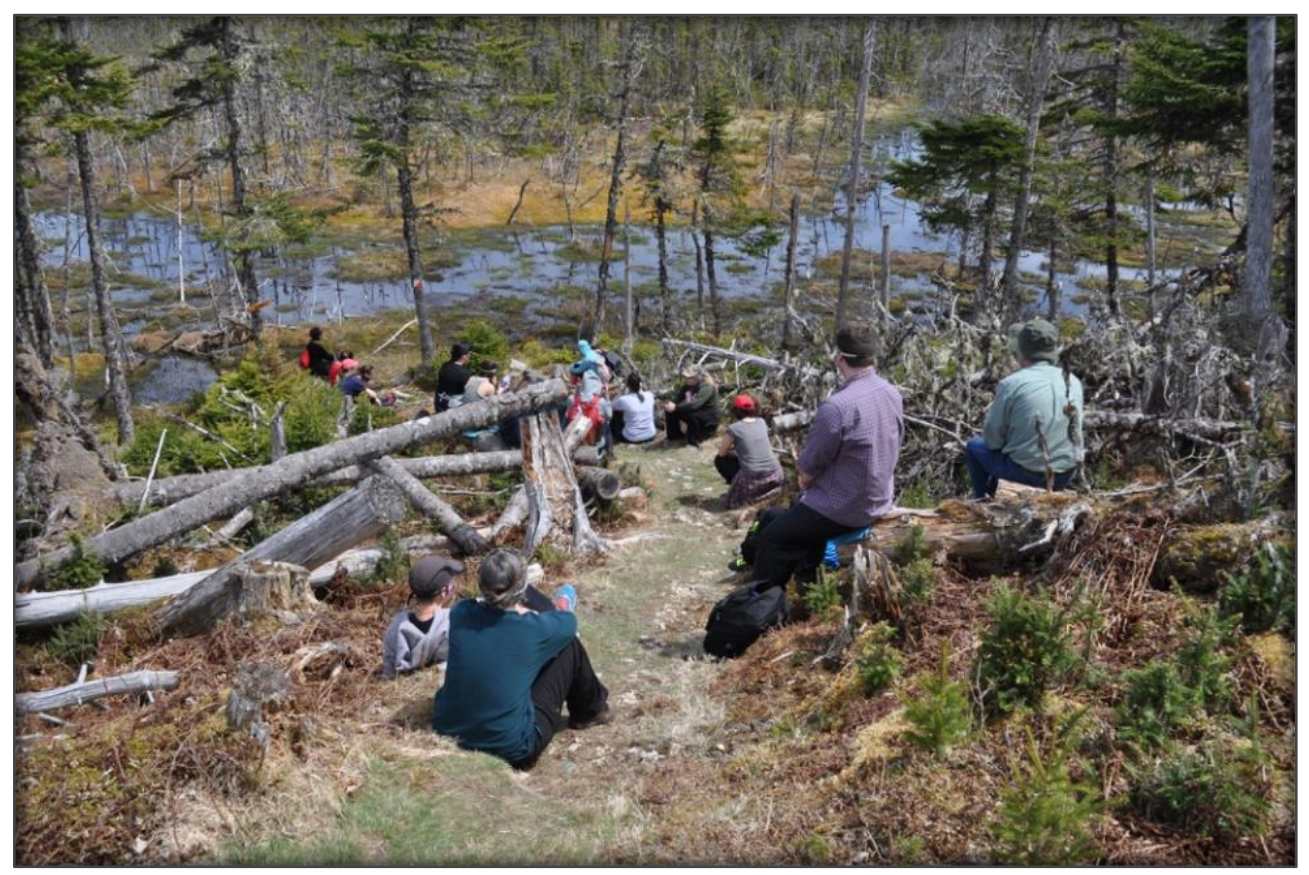

Students at the Brother Brennan Environmental Education Centre in Newfoundland

As we spread out, and the laughter and chatter subsided, there emerged an initial stillness, as if the students and the more-than-human inhabitants were holding their breath. But, within that silence, the hum of the Earth and all of its local inhabitants began to emerge. Far away from the human din that is often constant in our lives, our ears began to attune to what was already there. The close-by buzz of insects flying from plant to plant, the sighing of the wind in the trees and the chattering of so many different birds became stronger and louder, as if inviting us to be part of something we often ignore. 
The student teachers sat for half an hour using their sense of sound to become attuned to what many had never really paid attention to. At the end of the time, while the students were handing their blindfolds back, there was a continued silence, as if they did not want to break the spell that had been forged. Later, when they wrote about that day, many students shared how this moment was the most powerful one for them, as they realized that, in classroom teaching, often so much is focused on doing, keeping busy, moving children towards an indeterminate future; but the power of being still and silent taught the student teachers so much more. Even more importantly, questions about place began to emerge-profound questions. When we later stumbled upon a grey mass in the grass, and the instructors explained it was the entrails of a moose, the questions burst forth in an eagerness to understand this place better.

Newfoundland lore holds that, within any woods, fairies are abundant and need to be respected. After dinner, some students chose to go on a silent night walk with a centre instructor to look for fairies, to hear stories, and to learn the important ways of interacting with them. For example, they were encouraged to wear a piece of clothing backwards to protect themselves from being led astray by these mischievous, magical creatures. Newfoundland fairies are likened to the Greek God, Hermes-as mischievous tricksters waiting to entrance or cause trouble. The Newfoundland fairy stories mainly occur in the space where the "civilized world" and the wilderness intersect (Helesic, 2015). Through the folklore, reminders are made about the importance of the interconnectedness we have with nature and the respect this relationship demands (Rieti, 1991). The fairy stories offer an important connection between the history of the people of Newfoundland and the intimate and often difficult relationship with nature. By encouraging students to remember the past and attend to the relationship with their environment, the fairy story walk stood as an opportunity for them to feel connected both with the embodied encounters they had within the forests as well as with the people and the stories of the past.

As evening drew near and students were busy with different activities, I made my way to the short pier. As I sat there, watching the sun set, a sound broke over the quiet, misty waters and engulfed me in recognition and memories - the wail of a loon, answered by its mate, affirming that all is well. In that calling, I was reminded of similar moments, during my childhood, at a lake in Alberta. And in that calling I felt that I was being invited to my new home in Newfoundland from a familiar bird that was a part of both places. In the repetition of loon calling, I felt a familiarity and connection to my new home. It was an invitation of a bodily reclaiming — "rediscovering our embedment in the thick of things, remembering our real community and being remembered by that community" (Abram \& Jardine, 2000, p. 168). The forest, the loons and the fairy folklore were calling us back into relationships, relationships that we often ignore in standardized educational settings.

These experiences I have described regarding our time at the environmental centre demonstrate how walking and attending to what nature brought us deepened our understanding of what it means to learn from a teacher that is often ignored. Through quiet participation we were able to make connections with curriculum and the student teachers created wonderful units on how they could bring this experience to life in their own classroom. We were "drawn forth into a sense of 
indebtedness to our relational co-existence" (Jardine, 1998b, p. 71) with both human and non-human beings. As Derby (2015) declares, "everything echoes through the emptiness" (p. 4). By being silent within our walks and wanderings in the forest, we learned to attend to the cacophony of echoes and to make "room for various other non-human voices to enter and influence the general conversation" (Abram \& Jardine, 2000, p. 168). For us to learn something new, we had to have, and be had, by an experience that is a transformation of sorts, allowing for real learning to emerge. Quiet participation means attuning to the world around you while being changed by the stories that are told. As Abram and Jardine (2000) describe, it is through the sensuous experience of bodies of knowledge that are not just felt or experienced, but "mulled-over, taken seriously enough to not just be stimulating, but thought-provoking as well" (p. 172).

Although different stories about different places, the impact of noticing and walking invite the natural connections to emerge. I recognize how my experience with the loon's call and Josh's experience with the chickadee, that it is through these moments of strangeness and familiarity where new learning begins. When Josh recognized the newness of that chickadee, there was a knowing that this sound was different. From this awareness, the wonderful question of why emerged. Without the question, this would simply have been a brief moment of attention before moving off to something else; but instead, it became a rich exploration as to the wayfareness of the boreal chickadee.

Conversely, when I heard the familiar call of the loon in a new, unfamiliar place, I was invited into an exploration of the unfamiliar land in which I now was a part, creating the space for new understandings to emerge. Learning emerged out of each of our quiet participation.

\section{Fourth Step}

\section{(in which Josh walks beside a river)}

The Crowsnest Pass is a string of old coal towns along the banks of the Crowsnest River. It is about 100 kilometers west of where I (Josh) live now and is a place I often go to hike and fish. I recently fished one of my favourite stretches of the river with a friend. The two of us used to fish "the Crow" quite often, but we fish it together only occasionally now. I had a strange experience on my drive out there the morning of our recent trip: for a half-hour or so I could not, for the life of me, remember the passcode to my own cell phone. It was simply gone. And then came another test of

my memory. As we walked along the railroad tracks to the river, my friend asked me if I remembered a particular bug we had found on this stretch of the river a few years before. This, I remembered clearly: it was a strange looking bee fly collecting pollen from some tansy flowers. I recalled I had taken a photograph and sent it to an entomologist for further identification. A few hours into our excursion, fishing the river and walking its banks, I called out to my friend and pointed to a spot across the water: "Isn't that where we saw that bee fly?" The tansy had yet to bloom, but my friend confirmed it was, indeed, the spot. The river here bends gracefully to the south-east between undercut banks lined thickly with willow, shrubby cinquefoil and wild rose. The tansy, an invasive weed, would soon bloom just upstream of an outcropping of sandstone. We realized it must have been a few years since we fished this stretch together, because spotting that bee fly had occurred 
the last time. When I returned home, I searched my email history for "bee fly" and found the query and picture I had sent the entomologist: it was in 2010. It was an odd juxtaposition: I could not recall my own phone code that morning, but I could remember the precise location of a bug on a plant ten years earlier. And it felt like we had been on the river just yesterday.

Much like with the chickadee, this experience made me profoundly aware of how my body engaged with and was engaged by a place, and how intertwined that engagement was with my memory and sense of time. I believe that the different modes in which we inhabit a place, whether it be the carved banks of the Crowsnest river or the treed alleyways of my neighbourhood, can tell us something about the ways those places resonate and reverberate in our lives. Much like when I was looking for the boreal chickadee, a particular kind of place was brought forth by my mode of walking the stretch of the river. My sightline was now one of depression rather than elevation: instead of looking to the tree canopy, I focused instead on the flow of the river, its slick pools and tapering tailouts, nervous riffles and back-eddies. In contrast to the easy weave through the alleyways of my neighbourhood, here, I had to be sure with each stride, purposeful in each footfall. But, as with my walk alongside the boreal chickadee, I attended to the processes and actions underlying, pervading and sustaining a particular place.

On the river, I became more conscious of how I walked and what revealed itself to me. At the end of a wide bend in the river, I spotted what looked to be a nice run and stopped to get my fly rod in order. I cast a couple dozen feet of line out and watched my fly float downstream toward me. Much goes into being able to catch a fish on a fly rod. You need to choose the right fly, be able to cast effectively, present your fly to the water and maintain a drag-free drift. But the most important skill is in being able to read water. One could write a treatise on hydrology just by watching a fish in place. They will often sit in what we who fish call a seam: an indeterminate, shifting, shadowy line in the water column where two currents of differing speeds come together. The fish's place consists in an active tension. For the fish, those two currents must be like two different bodies of water. The tension lies between those bodies, and between the fish and those bodies. Remove a boulder or some other obstruction from just upstream and you might release that tension. And if you are not attending to that tension, you might just walk right on by.

\section{Fifth Step (in which Josh falls into step)}

These stories resonate in my (Josh's) practice as a high school educator. Most of my job was teaching high school mathematics but, for a period each day, I worked with a group of students in an alternative Grade 9 program. I was responsible for teaching these students, who had been mandated to this program for a variety of reasons, math and physical education. The class, a 90-minute block, was capped at 12 students, but seldom did more than five or six attend on a given day, so it was difficult to plan games and activities for them. They often had no interest in playing games, anyway. So, we walked together instead. 
In this section, I discuss some experiences I had walking with the students, and how we collectively attuned to one another and the places we walked, and how I was often slow to attune despite the quickening pace of my step. Pyne Feinburg (2016) writes that different places open themselves up to us differently: "while walking through a vibrant city, a school hallway, or amidst the Rocky Mountains may yield a phenomenologically distinct reaction, every environment successfully offers an opportunity to focus on how to attune to and interact with the environment" (p. 150). I experienced this firsthand with this group of Grade 9 students as we began to spend our time walking around the neighbourhood.

This class was typically confined to a stuffy classroom in an aging building. There was no air conditioning. Some days we would wear the smell of stale lunches and sweat like a heavy blanket. Of course, students were restless and fidgety. They slumped in their desks between walls we had all come to find oppressive. But this changed immediately when we began to walk outside. At first, we had fixed destinations: the park, about six blocks south and ten blocks west, and the bakery, eight blocks west. Then, after a while, we just walked together.

Throughout our stories, we have described walking as quiet participation. In discussing Merleau-Ponty's (1968) notion of language as flesh, Abrams (1996) evokes "our wordless participations ... our perceptual immersion in the depths of an animate, expressive world" (p. 84). For Merleau-Ponty (1968), the flesh is a liminal element in the co-creation of a place-world. Depending on how one orients one's body, or how one's body is oriented by place, one must also attend to other bodies in that place in a particular way. In his phenomenology of the skin, Casey (2015) notes that "we take in a place from the skin outward: it is the carnal this-side of every placial that-side" (pp. 170-171). This phenomenon began to reveal itself in our walking together. I did not realize why at the time, but we had come to pay closer attention to each other and the world around us. Our patterns of speech began to take on the rhythm of our walking together. More importantly, our silences did, too: rather than try and fill them with idle chatter, we let our silences speak and our bodies in place speak through them. Our participation with each other and the place we coinhabited was not quite wordless - they were teenagers, after all_but we let our bodies do some of the speaking, which often created quiet. Abram (1996) captures this phenomenon beautifully: "The enigma that is language, constituted as much by silence as by sounds, is not an inert or static structure, but an evolving bodily field. It is like a vast, living fabric continually being woven by those who speak" (p. 83). As Kearney (2015) writes, "in order to make flesh part of the world (mondanéiser) one needs to be not just oneself but oneself as another-a self with others" (p. 52).

My students and I went on another sort of walk once. It was to a river about an hour south of the city. I thought I would build on our walking through the neighbourhood and take the students to one of my favourite places to walk. I loaded them up onto our bus, and we drove the highway to an unmarked turnoff that I knew well. We drove down a right-of-way between farmers' fields, disembarked at a small clearing, and began our hike down to the river. At the trailhead, we could see the river come in from the west and disappear beneath the land before us. The trail wound down through some sedges and hawthorn then cleaved to a cliff's edge, the water churning below, before 
it opened onto a spade of gravel and grass that the river wrapped around in a big horseshoe. It was not long before I sensed something amiss on our walk. Students strung themselves out along the path. They seemed restless. For some of my students, an excursion to a river like this-what they called the wilderness, despite it being so close to home-was a new experience, so I chalked it up to a matter of acclimation. But when I caught a small fish and turned around excitedly to show them, I knew it was more than that. I was met with indifference, and we began our solemn walk back to the bus.

These walks were several years ago and, while I have reflected on these experiences often, it took a bird and a river to help me understand more deeply what was at play. The walk to the river differed from our walks in the neighbourhood in terms of our participation. Cajete's (2017) metaphor of tracking a story speaks to this. The Indigenous hunter, he writes, tracks prey through participating in an expressive and responsive world. "Tracking in the literal sense," he writes, "simply involves observing the 'rings' that are coming into you and quieting the rings that are going out from you" (Cajete, 2017, p. 118, italics added for emphasis). My recent experiences with birds and rivers have made this notion of quieting more resonant. The chickadee's solitary call rang out in concentric circles above and walking alongside it required me to quiet those rings emanating from me. I have had many similar experiences on the river. In his book The Habit of Rivers, Ted Leeson writes that the rise of a trout to a drifting insect reverberates in expanding, concentric ripples, magnified iterations of a simple event that resonate outward to encompass more and more, remaining visible long after and far from the thing that made them. The rings of a rising trout eventually comprehend the entire river, yet no matter how large their compass, like all circles they never cease to invite an inference of the center. (Leeson, 1994, p. 3)

Attuning myself to this invitation is difficult, but I realize now the quality of quiet participation - with each other, and with the place we brought forth together-that distinguished our walks in the neighbourhood from our walk by the river. Participation in this sense is not passive. The goal is not to silence the rings emanating forth, only to quiet them.

\section{Last Step \\ (in which we begin to infer from the center)}

We write this last step still amidst a pandemic. The boreal chickadee's call has ceased. It was intermittent, missing for a day or two, and now it is totally silent. Apparently, this happens with chickadees during nesting season, which makes them difficult for birders to spot. But its silence is just as revealing.

In each of the vignettes above, we have come to know differently and, thus, know these places differently. "Coming to know," Jardine (1998) writes, "whatever the discipline, whatever the topic or topography, is never just a matter of learning the ways of a place but learning about how to carry oneself in such a way that the ways of this place might show themselves" (Jardine, 1998a, pp. 94-95, italics added for emphasis). Walking in quiet participation is one such way of carrying oneself, and how we do so is intimately related to where we do so. Casey (2015) writes of how the body figures 
into the way a place reveals itself: "Body and place serve as covariables, intimately intertwined, so much so that we can formulate this approximate rule: change the place and there will be a corresponding change in the body in that place" (p. 164). We believe the converse to be true as well: change the body and there will be a corresponding change in that place. If we accept these premises, we must also accept the logical conclusion: body is place; place is body. They co-emerge.

We have drawn on our experiences in walking as quiet participation. This kind of walking allows us to participate in and realize place by attuning our bodies in such a way as to engage all of the senses. To hear the chickadee's call is to see its cinnamon flanks; to hear a loon's call is to be transported home; to feel the tension in a seam is to feel it underfoot on a riverbank. And walking this way is not wordless, but quiet. We are bodied beings and, as Kearney (2015) writes, our flesh is "the cradle of both perception and the word" (p. 38). But our bodies do not stop at our flesh. Rather, our bodies serve "as a precondition for the existence of all other sensations-visual, acoustic, olfactory, gustatory-which participate in it" (Kearney, 2015, p. 28). Walking with our students in this way allowed us to ease into conversation, to get to know one another more humanly than a confining classroom and curriculum would permit. When we began to simply walk with no destination or task in mind, it opened us to another kind of language, what Kimmerer (2013) might call a grammar of animacy. It opened us to "something more-something that is not for me, for which we have no language, the wordless being of others in which we are never alone" (Kimmerer, 2013, p. 48). It involved a bodily attunement-a realization that our understanding and experience of the world is not only mediated by the body, but sustained by it and the bodies of others, human and nonhuman. Walking together like this, in quiet participation, allowed each step to continue a story in ways mere words could not.

\section{About the Authors}

Josh Markle is a doctoral student at the Werklund School of Education, University of Calgary, and an instructor in the Faculty of Education at the University of Lethbridge.

Sharon Pelech serves as Associate Professor in Education at the University of Lethbridge, teaching at the undergraduate and graduate levels in curriculum studies and science education. Her research interests include science education, eco-pedagogy, place-conscious pedagogy and interpretive (hermeneutic) research.

\section{References}

Abram, D. (1996). The spell of the sensuous. Vintage Books.

Abram, D., \& Jardine, D. (2000). All knowledge is carnal knowledge: A correspondence. Canadian Journal of Environmental Education, 5(1), 167-177. https://cjee.lakeheadu.ca/article/view/307

Berger, J., \& Mohr, J. (1982). Another way of telling. Vintage Books.

Bird, D. M. (Ed.). (2010). Birds of Canada. Dorling Kindersley.

Cajete, G. A. (2017). Children, myth and storytelling: An Indigenous perspective. Global Studies of Childhood, 7(2), 113-130. https://doi.org/10.1177/204361061770383 
Cariou, W. (2014). Edgework: Indigenous poetics as re-placement. In N. McLeod (Ed.), Indigenous poetics in Canada (pp. 31-38). Wilfred Laurier University Press.

Casey, E. S. (2015). Skin deep: Bodies edging into place. In R. Kearney \& B. Treanor (Eds.), Carnal hermeneutics (pp. 159-172). Fordham University Press.

Derby, M. W. (2015). Place, being, resonance: A critical ecohermeneutic approach to education. Peter Lang.

Hasebe-Ludt, E., Chambers, C. M., \& Leggo, C. (2009). Life writing and literary métissage as an ethos for our times. Peter Lang.

Helesic, D. (2015, May 28). The fairy folklore of Newfoundland. Canadian Living. https://www.canadianliving.com/life-and-relationships/travel/article/the-fairy-folklore-ofnewfoundland

Jardine, D. (1998a). Birding lessons and the teaching of cicadas. Canadian Journal of Environmental Education, 3(1), 92-99. https://cjee.lakeheadu.ca/article/view/340/298

Jardine, D. (1998b). To dwell with a boundless heart: Essays in curriculum theory, hermeneutics and the ecological imagination. Peter Lang.

Kearney, R. (2015). The wager of carnal hermeneutics. In R. Kearney \& B. Treanor (Eds.), Carnal hermeneutics (pp. 15-56). Fordham University Press.

Kimmerer, R. W. (2013). Braiding sweetgrass: Indigenous wisdom, scientific knowledge and the teaching of plants. Milkweed.

Leeson, T. (1994). The habit of rivers. Penguin.

Merleau-Ponty, M. (1968). The visible and the invisible (A. Lingis, Trans.). Northern University Press.

Pyne Feinberg, P. (2016). Towards a walking-based pedagogy. Journal of The Canadian Association for Curriculum Studies, 14(1), 147-165 https://jcacs.journals.yorku.ca/index.php/jcacs/article /view/40312

Rieti, B. (1991). Strange terrain: The fairy world in Newfoundland. Institute of Social and Economic Research, Memorial University of Newfoundland. 